RESEARCHPAPER

\title{
Effect of low temperature storage of trichocards parasitised by Trichogramma chilonis (Ishii) and Trichogramma japonicum (Ashmead)
}

\author{
M. BHARGAVI AND K.V. NAIK \\ Department of Agricultural Entomology, College of Agriculture, Dr. Balasaheb Sawant Konkan Krishi Vidyapeeth, \\ Dapoli, RATNAGIRI (M.S.) INDIA \\ Email : baachi.agbsc@gmail.com; kumudnaik@yahoo.in
}

Article Info :Received : 08.12.2014; Revised : 14.02.2015; Accepted : 28.02.2015

The present investigations were undertaken on laboratory studies of Trichogramma chilonis (Ishii) and Trichogramma japonicum (Ashmead) during the year 2013-2014 in the bio-control laboratory, Department of Agricultural Entomology, College of Agriculture, Dapoli (Maharashtra). Effect of low temperature storage at $15^{\circ} \mathrm{C}$ temperature for varying period on egg cards parasitised by $T$. chilonis and T. japonicum, 4 day after parasitisation revealed that parasitised trichocards after 4 days of parasitisation can effectively stored up to 15 days without much effect on adult emergence.

Key words : Adult emergence, Parasitisation, Trichogramma chilonis, Trichogramma japonicum

How to cite this paper : Bhargavi, M. and Naik, K.V. (2015). Effect of low temperature storage of trichocards parasitised by Trichogramma chilonis (Ishii) and Trichogramma japonicum (Ashmead). Asian J. Bio. Sci., 10 (1) : 43-47. 